those of rheumatoid arthritis are occasionally encountered in apparently healthy people; in adults they may presage the onset of sero-positive arthritis, but in children the prognosis is good and rheumatic disease is not likely to supervene. ${ }^{34}$

It has been suggested on morphological grounds that the fibrinoid areas are due to swelling or coagulation of the ground substance of fibrous tissue with subsequent infiltration by fibrinous exudate. ${ }^{56}$ Other investigators have described swelling of collagen fibres or suggested that the essential defect is a precipitation of the acidic mucopolysaccharides of the connective tissue. ${ }^{7}$ The necrotic foci contain tyrosine and polysaccharides (as judged by periodic acid Schiff staining) but reactions for acidic polysaccharides are weak or absent. ${ }^{8}$ Since fibrinous exudates also give these and other staining reactions some observers have concluded that the fibrinoid is really nothing more mysterious than a deposit of fibrin in inflamed connective tissue. ${ }^{9}$ In an attempt to find out more about the composition of the nodule J. $\mathrm{H}$. Kellgren and his colleagues ${ }^{10}$ examined parts of it with the electron-microscope and by $x$-ray diffraction. They found no fibrin. The necrotic foci differed from the surrounding fibrous tissue in containing fewer, but structurally normal, collagen fibrils, and much more amorphous material which did not appear to be collagen protein. The non-collagenous nature of the amorphous moiety was apparently confirmed biochemically, ${ }^{11}$ so it seems unlikely that the lesion follows the precipitation of some collagen precursor.

In a more recent study of the ultrastructure of the rheumatoid nodule W. Cochrane and colleagues ${ }^{12}$ also found that the collagen present has a normal appearance and is neither swollen nor fragmented. They further showed that the necrotic foci contain an abundance of cellular remnants (indicating that the areas have at one time been highly cellular) and much granular and filamentous material. The filaments could not be positively identified as fibrin. However, both the staining properties ${ }^{13}$ and the ultrastructure of fibrin probably depend on the conditions in which it is formed and possibly on its age, so that its certain identification can present technical difficulties. There are in fact few observations on the early stages of the lesion. L. Sokoloff and colleagues $^{14}$ found that the nodule is heralded by oedema of connective tissue and growth of granulation tissue, and that the fibrinoid develops in relation to blood-vessels. That fibrinoid foci indistinguishable from those in the subcutaneous nodule can arise in pre-existing granulation tissue seems certain from Kellgren and J. Ball's studies of the tendon lesions in rheumatoid arthritis. ${ }^{15}$ Focal necrosis in granulation tissue-one cause of which might be pressure trauma -could account for the observed changes in the established nodule.

\footnotetext{
1 Kellgren, J. H., and Ball, J., Brit. med. F., 1959, 1, 523.

Bywaters, E. G. L., Glynn, L. E., and Z̈eldis, A., Ann. rheum. Dis., 1958, 17, 278.

1958, 17, 278. Lowney, E. D., and Simons, H. M., Arch. Dermatol., 1963, 88, 853.

Beatty, E. C., Arch. Path., 1959, 68, 154.

Klinge, F., Erg. Path., 1933, 27, 1.

- Bahrmann, E., Virch.' Arch., 1937, 300, 342.

'Altshuler, C. H., and Angevine, D. M., Amer. F. Path., 1949, 25, 1061.

- Montgomery, P. O'B., and Muirhead, E. E., ibid., 1957 33, 285.

- Movat, H. Z., and More, R. H., Amer. F. clin. Path., 1957, 28, 331.

10 Kellgren, J. H., Ball, J., Astbury, W. T., Reed, R., and Beighton, E., Nature (Lond.), 1951, 168, 493.

11 Ziff, M., Kantor, T., Bien, E., and Smith, A., F. clin. Invest., 1953, 32, 1253.

12 Cochrane, W., Davies, D. V., Dorling, J., and Bywaters, E. G. L., Ann. rheum. Dis., 1964, 23, 345.

1s Gitlin, D., and Craig, J. M., Amer. F. Path., 1957, 33, 267.

11 Sokoloff, L., McCluskey, R. T., and Bunim, J. J., Bull. N.Y. Acad. Med., 1953, 29, 733.

${ }^{15}$ Kellgren, J. H., and Ball, J., Ann. rheum. Dis., 1950, 9, 48
}

Clearly there are many gaps and uncertainties in our knowledge of the nodule. Future studies by both traditional and more sophisticated methods of tissue analysis might with profit pay particular attention to the early stages of its development.

\section{Treatment of Depression}

The most powerful treatments of depressive illness now available are electric convulsion therapy (E.C.T.) and the two groups of antidepressant drugs, imipramine (Tofranil) and its analogues and the monoamine oxidase inhibitors. The value of E.C.T. in depressive illness, particularly when given during the period of mental involution characteristic of the second half of life, is firmly established, but in spite of many trials there is still disagreement about the efficacy of antidepressant drugs and the specific indications for prescribing any one of them. This is partly due to problems of psychiatric terminology and partly to inadequacies in the design and reporting of drug trials, so that all too often it is impossible to make a valid comparison of one group of patients with another.

The Medical Research Council's Clinical Psychiatry Committee has now completed a six months' trial on 250 patients, and its report appears at page 881 of the B.M.F. this week. It was designed to compare the merits of imipramine and a monoamine oxidase inhibitor, phenelzine (Nardil), in the treatment of depressive illness, and to compare the effects of these drugs with those of E.C.T. and a placebo. In view of the difficulties of carrying out a trial of this nature and scope, both the design and the way in which it has been executed and reported upon deserve the highest praise. Patients spent the first four weeks in hospital, but subsequently became out-patients unless there were clinical contraindications. Each patient was allocated randomly to treatment for a minimum period of four weeks by imipramine, phenelzine, E.C.T., or placebo. If at the end of this period the response was poor, treatment could be changed.

About one-third of the patients recovered on the placebo alone, a figure which probably reflects the effects of sociopsychological factors together with the tendency of depressive illness to improve spontaneously. Treatment either with imipramine or with E.C.T. increased this recovery rate considerably, but phenelzine appeared to be no more effective than the placebo. At this point it is important to recognize that the majority of patients included in the trial probably had a severe endogenous type of depressive illness. All were aged between 40 and 69 years and in addition to feeling and looking depressed showed one or more of the following symptoms: self-depreciation with a morbid sense (or delusional ideas) of guilt; sleep disturbance; hypochondriasis; retardation of thought and action; agitated behaviour. Many psychiatrists believe that imipramine is most effective in the treatment of endogenous depressions, while monoamine oxidase inhibitors such as phenelzine are more useful in exogenous or reactive depression, particularly when anxiety is prominent. ${ }^{1}$ It is not surprising, therefore, if this is so, to find that phenelzine in this trial is no more effective than a placebo. If exogenous or reactive depression

\footnotetext{
Brit. med. 7., 1964, 2, 522.

Ibid., 1964, i, 770.
} 
had been prominent in these patients the findings might have been different.

The M.R.C. investigators found that initially E.C.T. was the most effective treatment, more than doubling the placebo rate of recovery. But after about the eighth week and for the remainder of the trial period the results of treatment with imipramine were as good as those from E.C.T. All the antidepressant drugs tend to show a time lag between starting treatment and clinical improvement, but with imipramine in particular improvement is often slow although progressive. Therefore, where quick results are needed, and particularly when a patient is suicidally depressed, E.C.T. is to be preferred to this drug. There is no reason why E.C.T. and imipramine should not be combined, thereby reducing the total number of E.C.T. sessions needed. It is important not to withhold E.C.T. unduly long if a patient's response to the antidepressant drug is incomplete. One-third of the patients on imipramine who failed to respond satisfactorily after four weeks' treatment were subsequently given E.C.T. and half of them responded fully.

No reliable prognostic indicators, ${ }^{2}$ clinical or social, could be identified in patients responding or not responding to different treatments, and about $20 \%$ failed to improve at all on any treatment. We may have reached a stage when only the biochemist can tell us why.

\section{Autoimmunity in Myasthenia Gravis}

Clinical observations on $\mathbf{4 4 0}$ patients first led J. A. Simpson ${ }^{1}$ to suggest that myasthenia gravis might be an autoimmune disease, and his more recent report ${ }^{2}$ lends further weight to this hypothesis. The disease runs a fluctuant course, is twice as common in women as in men, and has its maximum

ISimpson, J. A., Scot. med. F., 1960, 5, 419.

F. Neurol., Neurosurg. Psychiat., 1964, 27, 485.

Myasthenia Gravis: Second International Symposium Proceedings, ed. H. R. Viets. Springfield, Ill. 1961.

'Russell, D. S., F. Path. Bact., 1953, 65, 279.

Cruickshank, B., ibid., 1952, 64, 21.

- Engel, A. G., Arch. Neurol. (Chic.), 1961, 4, 663.

'Denney, D., and Rose, R. L., Neurology (Minneap.), 1961, 11, 710.

- Daly, J. J., and Jackson, E., Brit. med. F., 1964, 1, 748 .

- Becker, K. L., Titus, J. L., McConahey, W. M., and Woolner, L. B., f. Amer. med. Assoc., 1964, 187, 994.

10 Thiodet, J., Fourrier, A., Arroyo, H., and Sudre, Y., Bull. Soc. Med. Hop., Paris, 1961, 77, 289.

"Harvey, A. M.., Schulman, L. B., Tumulty, P. A., Conley, C. L., Schoenrich, B. H., Medicine (Baltimore), 1954, 33, 291.

1s White, R. G., and Marshall, A. H. B., Lancet, 1962, 2, 120.

18 Alarcón-Segovia, D., Galbraith, R. F., Maldonado, J. E., and Howard, F. M., ibid., 1963, 2, 662 .

16 Feltkamp, T. E. W., van der Geld, H., Kruyff, K., and Oosterhuis, H. J. G. H., ibid., 1963, 1, 667.

16 Castleman, B., and Norris, B. H., Medicine (Baltimore), 1949, 28, 27.

10 in Tumours of the Thymus Gland ; sect. V, fasc. 19, Washington. 1955.

17 Sloan, H. E., Surgery, 1943, 13, 154.

18 Gunn, A., Michie, W., and Irvine, W. J., Lancet, 1964, $2,776$.

10 Helyer, B. J., and Howie, J. B., ibld., 1963, 2, 1026.

10 Miller, J. F. A. P., ibid., 1963, 1, 43.

"Sutherland, D. E. R., Archer, O. K., Peterson, R. D. A., Eckert, E., and Good, R. A., ibid., 1965, 1, 130

22 Strauss, A. J. L., Seegal, B. C., Hsu, K. C., Burkholder, P. M., Nastuk, W. L., and Osserman, K. E., Proc. Soc. exp. Biol. (N.Y.), 1960, 105, 184. 28 Feltkamp, T. E. W., van der Geld, H., and Oosterhuis, H. J. G. H., Vox Sang., 1963, 8, 317.

${ }^{24}$ Van der Geld, H., and Oosterhuis, H. J. G. H., ibid., 1963, 8, 196

${ }_{25}$ Djanian, A. Y., Beutner, E. H., and Witebsky, E., F. Lab. clin. Med., $1964,63,60$.

26 Van der Geld, H., Feltkamp, T. E. W., Loghem, J. J. van, Oosterhuis, H. J. G. H., and Biemond, A., Lancet, 1963, 2, 373 .

27 Grob, D., Himei, H., and Namba, T., Y. clin. Invest., 1964, 43, 1273.

28 Stern, G. M., Hall, J. M., and Robineon, D. C., Brit. med Э. 1964, $2,284$.

"9 Schwarz, H., Canad. med. Ass. Э., 1952, 67, 238. incidence in the second and third decades of life. It is characterized by a muscular weakness increasing after exercise, which appears to be due to an interference with the passage of the neural impulse across the motor end-plate. ${ }^{3}$ In addition there is a general myositis similar to that seen in disorders of connective tissue. ${ }^{45}$

The frequent association with thyrotoxicosis has long been recognized, ${ }^{6}$ and more recently there have been reports of myasthenia in combination with Hashimoto's thyroiditis, 28 Addison's disease, ${ }^{10}$ systemic lupus erythematosus, ${ }^{11-13}$ and rheumatoid arthritis. ${ }^{12} 14$

Abnormalities of the thymus are present in most myasthenic patients and include tumours, germinal follicles, and delayed involution. ${ }^{12} 1516$ Thymic hyperplasia has also been reported in two-thirds. of thyrotoxic patients ${ }^{17}{ }^{18}$ and in association with Hashimoto's thyroiditis ${ }^{18}$ and Addison's disease. ${ }^{17}$ There is also conspicuous thymic hyperplasia in the New Zealand black strain of mice which develop autoimmune haemolytic anaemia. ${ }^{19}$ These abnormalities are particularly relevant in view of the control which the thymus exercises over the development and maintenance of the immune mechanisms. $^{2021}$

More direct evidence of autoimmunity in myasthenia gravis was obtained by finding complement-fixing antibodies to skeletal muscle in $40-50 \%$ of these patients. ${ }^{22-25}$ An increased incidence of other autoantibodies has also been found in patients with myasthenia. Thus, antinuclear factors can be detected in one-third of cases ${ }^{126}$ and specific thyroid and gastric antibodies are also increased. ${ }^{26}$

Antibodies to muscle can occur in severe cases of myositis without myasthenic symptoms, and therefore it has been postulated that inhibition of neuromuscular transmission is brought about by other antibodies directed against a component of the motor end-plate. ${ }^{27}$ The transient neonatal myasthenia occasionally seen in babies born of affected mothers could be due to the placental transfer of such antibodies. $^{28}$ However, transfusions of myasthenic blood to normal adults does not produce muscular weakness. ${ }^{29}$

\section{Micturition Induced by Giggling}

Stress incontinence on laughter, particularly if the person is also excited, and incontinence on sneezing are well known. Somewhat different is the problem of involuntary micturition during giggling. It can cause much embarrassment, and unkind school-fellows may invent unpleasant nicknames for the sufferers or even ostracize them because of the smell. R. C. Mac. Keith ${ }^{1}$ has written an excellent review of the problem, describing five cases seen by himself and mentioning others which have been reported to him by correspondents after his paper on the subject at the annual conference of the British Paediatric Association at Scarborough in 1959.

In three of the five cases the mother had the same symptoms. The children were aged 5 to 13 , three of them being boys. After discussing the role of superadded anxiety and the known reduction of muscle tone with laughter, Mac Keith discards any suggestion that cataplexy or epilepsy is an important factor. He thinks that it is more likely, in view of the family history, that there is some inherited functional anomaly, and that the absence of stress incontinence and the

\footnotetext{
1 Mac Keith, R. C., Guy's Hosp. Rep., 1964, 113, 250.
} 